\title{
FLEXPO 2004 New Innovations in Polyolefins \& Elastomers, Sep. 15-17, Galveston/Huston, TX
}

\author{
座 間 義 明*
}

2004 年 9 月 15 日〜 17 日にテキサス州 Galveston 市で開 催された「FLEXPO 2004 New Innovations in Polyolefins \& Elastomers」に参加した。参加者名簿には 163 人 (去年 (183人)より若干少ない)が登録されていて, 日本人の参 加者は 2 名であった.ゴム協会誌にこれまでこの会議のこ とが紹介されたことはないが，その内容の一部を紹介した い.

FLEXPOはコンサルタント会社のCMR (Chemical Market Resources Inc.) が主催. 世界で最も大きな石化産業集 積地であるメキシコ湾岸エリアを中心に世界有数の石化企 業(ExxsonMobile, BP Amoco, Basell, Dupon, Dow, Shell Chemical, Formosa, AtoFina, SABIC等)が集まって, 石 油化学関連の技術，ビジネスについて情報交換をおこなっ た. 去年と比べて, 原料高はあるものの, 市況が回復して いるため，収益が上がっている会社が多いようで活況であ った.

開催場所はテキサス州 Houston 市から車で約 1 時間南へ 走ったGalveston市のリーゾートホテルThe San Luis Resort. 開催日時は 9 月 15 日から 17 日の三日間. Galveston市はメキシコ湾を臨む風光明媚な観光都市で, 海水 浴場に面したThe San Luis Resortからはメキシコ湾が一 望にでき, 参加者もリラックスした雲囲気で会議に参加し ていた。

\section{1. 石油化学産業とプラスチック産業に対するエネルギ 一問題の世界的状況と影響}

Mr.Peter J, Killen, Senior Advisor, Muse Stancil, Huston, TX

最近の世界的な原料，エネルギーの高騰を受け，天然ガ ス会社からの講演.メキシコ湾岸地区の石油化学産業は天 然ガスからできるメタノールを主原料にしている。また， 生産時のエネルギーも天然ガスに依存している。講演は最 近の天然ガスおよび石油の価格高騰とそれの将来動向, お よび米国石油産業の将来的な競争力について解説してい

\footnotetext{
* JSR AMERICA, INC.

(312 Elm St., Suite 1585 Cincinnati, Ohio 45202, USA)
}

た.

最近のメキシコ湾岸地域の天然ガスの価格は高騰してお り, 同地域の石油化学産業の競争力低下が懸念されている. さらには,石油化学関連の増設計画を世界的に比較すると, 北アメリカは中東, 中国, ヨーロッパに大きく遅れを取っ ている. 特に中東の増設計画はすさまじく, 現行能力の 5 倍もの増設計画があり，北アメリカでの増設計画に対して も約 5 倍になる. 現行能力と計画能力を合計すると中東地 域は北アメリカの 1.5 倍の生産能力を持つことになり, 原 料面での中東地域の優位性と合わせて, 非常に妿威である.

このような状況に対して,メキシコ湾岸地域の石油産業 はどのような戦略を描くべきかを論じられていたが，1. 古い設備をリタイヤさせて生産効率向上の設備投資を行 j，2．品質と信頼性を高く維持する， 3 ．高付加価值製 品へのシフトなどの方法が提案されていた。

\section{2. ポリオレフィン工業における中東の役割}

Dr, Faisal H, Syed, Chemical Market Resources, Houston, $\mathrm{TX}$

ポリオレフィン産業界において最近，特に注目を浴びて いるのは，ポリオレフィン消費国としての中国と供給国と しての中東の動向である.この講演では，中東の現状と将 来について概括した．特に中東最大の石油化学会社でサウ ジアラビアの国策会社のSABICについて詳細に紹介した。

中東地域の石化製品の世界におけるシェアは現在のとこ ろ, エチレン：9\%, プロピレン： $3 \%$ ，ポリエチレン： $9 \%$ ，ポリプロピレン：4\%である.しかし，これらは急 速に成長することが見达まれている，エチレンを例に取る と, 中東以外の地域の 2003 年から 2008 年までの平均年成 長率が $2 \%$ と予測されているのに対し, 中東地域はなんと $17 \%$ と予測されている. 2008 年には 2003 年の 3 倍の生産 能力をもつ予定である.

SABIC はサウジアラビアの国策会社として 19.76年生ま れ，基礎化学製品，中間原料，ポリオレフィンを主な製品 として製造している. SABICの特筆すべき特徴は，その 収益性の高さである。そのNetマージンは景気の良いとき 


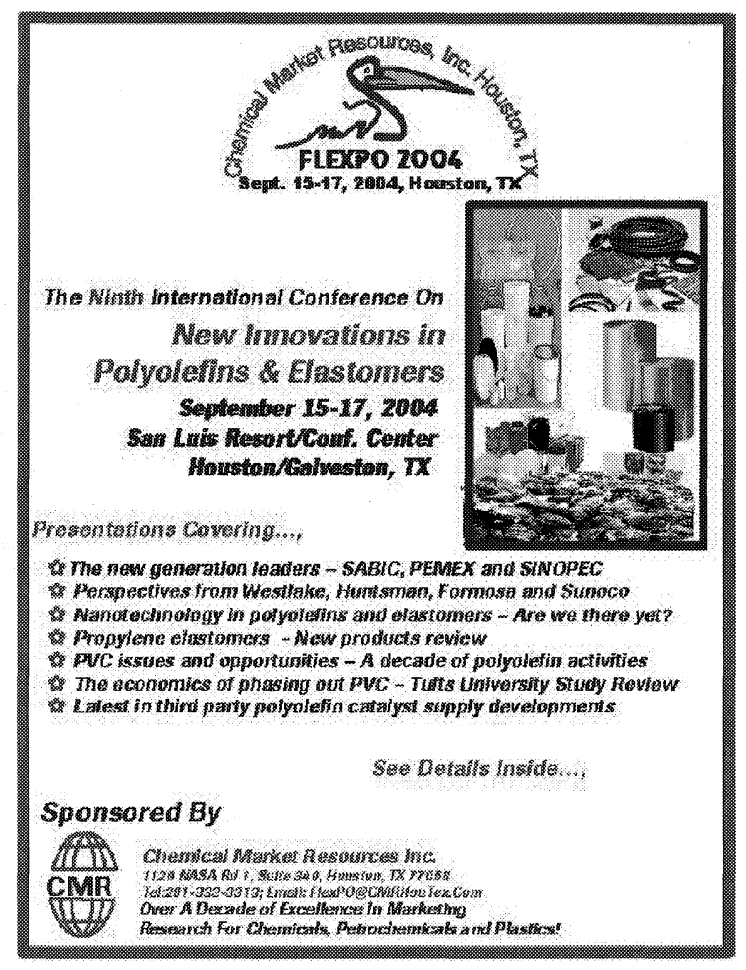

図1 FLEXPO 2004のポスター

でも悪いときでも常に他の化学会社 (Dow, ExxonMobile, Equistar, Reliance) より良好である。 また，売り上げに対 する収益率は，スペシャリティ製品がほとんどないにもか かわらず，ほとんどスペシャリティ製品以外は製造販売し ていないGEを凌ぐ. SABICは今後の五年間で売り上げを 40\%伸ばす計画を立てている.

\section{3. 世界的なポリオレフィン産業に対するプライベート} エクイティ投資の展望

Mr, Jeffrey W, Dancer, The Allan F, Dow Group LLC, Houston, TX

巨大なプライベート投資会社がポリオレフィンビジネス の投資に扔いて役割を増している．その傾向はますます増 加するようである. 最近では, クレイトン, クロンプトン, ハンツマンなどが投資会社に買われている. どうして投資 会社は石油化学産業に投資をするのであろうか？S\&Pの 企業価值指標によると 1990 年から 2000 年の間に全体で $418 \%$ の企業価值上昇が見られたのに対し，化学，プラス チックのそれは $241 \%$ 上昇に過ぎなかった。しかし， 2001 年から 2004 年では全体で $14 \%$ 低下が見られたのに 対し，化学，プラスチックのそれは $24 \%$ 上昇した。つま り，投資効率が他産業より優れているから投資するのであ る. 長期的に見れば, 米国石油化学産業の将来が有望視さ れているわけではない.プライベート投資会社は期間を限 って，企業価值を上げられる可能性があるところに投資す る.ゆえに，長期的な基礎技術開発や，計画にない有望技 術への投資等は一切行わない。演者は個人的には，プライ
ベート投資会社がポリオレフィン産業を買い取ることをい いことだとは思わないといっていた，長期的な観点からの 技術開発への投資がなされなくなるからである.しかし， プライベート投資会社の投資が石油化学産業を活性化させ ることも事実である。そここで，プライベート投資会社に投 資してもらうにはどのようにすればよいか解説していた.

\section{4.インド石油化学および化学産業の将来性}

Mr, Pratyush Sinha, Ministry of Chemicals \& Fertilizers, Ms, Veenu Gupta Department of Petrochemicals

インド政府機関よりの参加.インド経済の現状と将来性, およびインド石油化学および化学産業の現状と将来性につ いての講演。またINDIA CHEM 2004(11月 3 日から 5 日 までボンベイで開催)の紹介があった.

インドは世界でもっとも大きな民主主義国家で，その十 億の人口により,世界で二番目の潜在的マーケットをもち， 世界で 4 番目の経済大国である。また，質の高い，教育さ れた人材も豊富で, その将来性は非常に高い.インドの化 学産業はインド全製造業の中の $16 \%$ 占め, インドの全 貿易額の $9 \%$, 特に輸出の $14 \%$ 占める，成長率は 9 か ら $14 \%$ と GDP成長率の約二倍で, 全投資額の $9 \%$ とイン ドで 3 番目の投資分野である. 化学産業はインド経済を推 進する三つの分野のうちの一つである.

このように急速に成長するインド化学産業には，外国か らの近代化投資が是非必要で, 貿易相手として最も大きく (16\%)，インド経済と強い結びっきを持つアメリカから のよりいっそうの投資を呼びかけていた.

\section{FORTE ナノコンポジットー問題解決をするためのブ レークスルー}

Mr, Timothy Patterson, Business Unit Leader, Noble Polymers

Mr, Taher Abujoudeh, Director of Materials Engineering, Cascade Engineering

Noble PolymerがCascade Engineering と共同で開発し たナノコンポジット材料FORTEシリーズの紹介.

FORTEはPPベースのナノクレーコンポジットである. ナノクレーを適切にデラミネートさせながら PP と混合す ることにより, クレーが均一に分散，配向したナノコンポ ジットを得ることができる，それのために特殊な二軸共押 出機を開発した，FORTEはニートPPに対し，引っ張り 強度, 剛度, モジュラスが 20 から $30 \%$ 高い. $20 \%$ ガラス 瀻維強化PPに対しても，10から 15\%の引っ張り強度と伸 びの改善が見られる。 また，成形性にすぐれ，成型外観が 良好, 低比重, 低コスト, 耐摩耗性に優れるなどの特徴が ある. 応用例として, 自動車の座席の部品が上げられてい た. 現行の 30\%ガラス強化PPを Forte 35CPP091にする 
ことにより, 部品重量が3.75lbsから 3.001bsに低減，部品 あたりのコストを $\$ 0.27$ 下げることができた。 しかも成型 加工性がより良好になったとの評価を得た。

次の応用例として, 自動車コンソールが上げられていた. 現行の $13 \%$ \%゙ラス強化PPを Forte 18CPP091にすること により，部品重量が4.11bsから 3.61bsに低減．部品あたり のコストを $\$ 0.32$ 下げることができた.

\section{6. カーボンナノコンポジットー異なる沉用ポリマーヘ の応用}

Mr, Tom Hughes, CEO, Applied Sciences, Inc. Cedarville, $\mathrm{OH}$

直径 $100 \mathrm{~nm}$ のカーボンナノチューブ，商品名 Pyrograf IIIの紹介フプラスチックに混入することにより，電気抵 抗を下げ，強度を上げることができる．

PyrografIIIは金属触媒を使用し，天然ガスから製造す る。アスペクト比は500から 1000 程度. PyrografIIIのグ レードには，表面に化学蒸着層のついたPR19 とついてい ないPR24がある．また，それぞれに表面状態の異なるグ レードが 3 種類ずつあり，全部で 6 グレードある.

カーボンナノファイバーをポリオレフィンに入れると電 気抵抗が下がり，電気伝導度が向上する，PyrografIIIは， グレードによっては，たった 3 体積\%入れるだけで，飛躍 的に電気伝導度を向上させるものがある．電磁波シールド 用材料は $1 \mathrm{~S} / \mathrm{om}$ 以上の伝導性が要求されるが，従来の単 壁のカーボンナノナチューブだと 30 体積\%以上樹脂に混 ぜる必要があるのに対し，PyrografIIIは10\%程度でよい． $1 \mathrm{lb}$ の電磁波シールド材料を製造するのに従来の単壁カー ボンナノチューブは $\$ 16,000$ かかるのに対し, PyrografIII

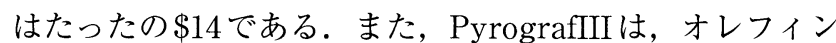
樹脂の温度による体積膨張を防ぎ，引っ張り強度を $50 \%$ 程度向上させる。また，ナイロンのような極性樹脂に混ぜ ても，同じ効果が期待できる。価格は最も安いもので $\$ 85 / \mathrm{lb}$ と，以前に比べてだいぶ安くなった.

\section{VISTAMAXX ファミリー製品でのTPO改質の革新的 アプローチ}

Dr, Raja Dharmarajan, Staff Engineer, Dr, Sudhin Datta, Product Technology Research Associate, Mr, Glen Williams, Research Engineer,

ExxonMobil Chemical Company, Baytown, TX,

ExxonMobileの新製品 VISTAMAXX の TPO改質材と しての用途に関する発表.VISTAMAXXは2004年 6 月に 新製品として上市を行い，不織布，繊維コーティング等に 広く使用されている.ルイジアナ州Baton Rouge工場で 製造.VISTAMAXX は低結晶性 Isotactic ポリプロピレ ンーエチレン共重合体で，プロピレンリッチな領域（80\%

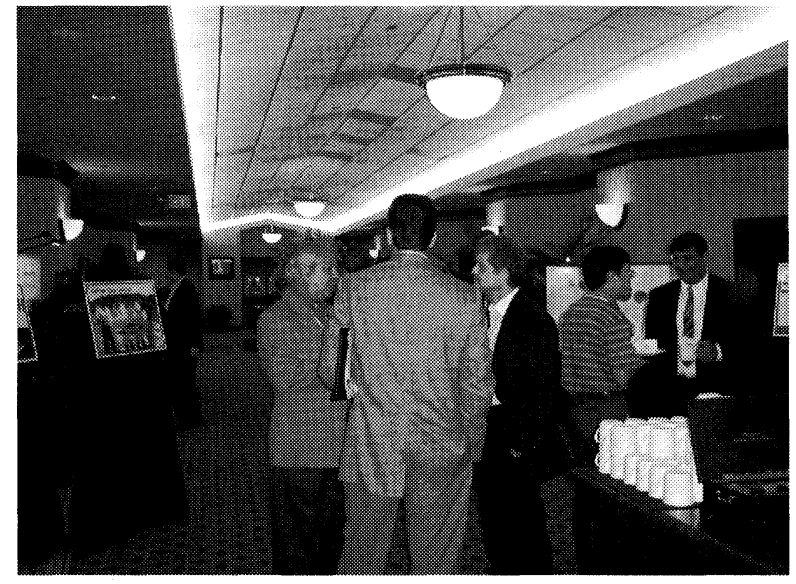

図 2 会場風景

程度)にあるメタロセン触媒系ポリオレフィンエラストマ 一である.VISTAMAXXにはPP改質材として二つの使 用方法が考えられる。一つ目は柔軟性付与材として，二つ 目は相溶化剤である。柔軟性付与材の用途としては，耐候 性を生かして，ルーフィング用TPOが上げられていた。

該社のプラストマーEXACT0201 と比較すると，特に Modulus15\%が劇的に低下する。VISTAMAXXはPP と の相溶性が優れるため，PPに柔軟性を付与する効果が高 い.

また，相溶化剤としてVISTAMAXXを使用すると，衝 撃強度が飛躍的に向上し，剛度は維持される．衝撃強度と 剛度のバランスに優れる．電子顕微鏡写真で見ると，VISTAMAXXがひげ状にPP/EOM界面に張り出して，界面 接着を助けていることが伺われた。

\section{8. フレキシブルTPOへの応用における VERSIFY エラス トマーの可能性}

Ms, Seema V, Karande, Technology Leader, Dr, Li-Min Tau, Sr, Research Engineer

Mr, Ronald Wevers, Sr, Research Chemist,

The Dow Chemical Company, Freeport, TX

該社の新しく開発したポリプロピレンベースのプロピレ ンー $\alpha$-オレフィンコポリマー，商品名VERSIFY の紹介と その応用例の紹介. VERSIFYはINSITEテクノロジーを 使ったガスフェイズメタロセンポリマー．狭い分子量分布 とユニークなコモノマー組成分布を有する，第一世代は 桂レフィとしてエチレンを使用していたことから も，ExxonMobileのVISTAMAXX 対抗品の位置づけのよ う.

第一の性能上の特徵はプロピレンとブレンドして TPO としたときにFlexural Modulusが下がり，柔軟性が付与 できること．第二の性能上の特徵は TPO の熱軟化温度が 高く，したがって常用温度も高くなること．第三の特徴は TPOの透明度が高いこと．第四の特徴として TPOの屈曲 
性が高いこと。

VERSIFY を用いたTPO は自動車.用ソフトタッチコン パウンド，家庭用耐久消費財，ルーフィングシート，人工 皮革などの応用例が考えられる。

\section{9. 塩ビの製品の展望}

Mr, Keith Christman, Director - Industry Affairs, The Vinyl Institute, Arlington, VA

塩ビ協会からの講演．環境問題で攻撃の対象になってい る塩ビを全面的に擁護する内容．塩ビは北米で，その使用 量の $2 / 3$ が建設用資材に使用されている。 その内訳はパ イプ，パイプの付属品に $47 \%$ ，サイジングに $15 \%$ ，空， ドア枠に $9 \%$ ，フローリングに $3 \%$ な゙である。塩ビは 2004 年の米国とカナダで $4 \%$ の需要の伸びが見达まれ， プラントの操業率が $90 \%$ 以上に達する，塩ビは作業者に 安全で，コミュニティに安全で，環境を保護する。

環境におけるダイオキシンの発生が塩ビのせいにされて いるが，精錬所やセメントキルンからの発生量のほうがは るかに多い。また1970年からダイオキシンの放出はどん どん下がってきている．それは地方自治体の燒却炉からの 放出が減ったからである。ダイオキシンは1970年をピー クに低下しているが，塩ビの消費量は增え続けている。こ のことからも，ダイオキシンの発生と塩ビは因果関係がな いことがわかる．さらに医療機器の塩ビで問題視されてい るフタレート系可塑剤もFDAが認可して抢り，招もちゃ への使用を禁止する活動家の嘆願も却下された。

\section{0. 塩ビ段階的削減の経済学}

Dr, Frank Ackerman, Global Development \& Environment Institute

Tufts University, Medford, MA

塩ビを段階的に削減，廃止することに対する総合的経済 メリットを提唱. 塩ビ廃止論を展開.

塩ビはビニルクロライド，ダイオキシンなどの発がん性 物質を製造時に発生させる。また，有毒な可塑剤，重金属 などの安定剂を含有する，さらには，焼却炉，火事などで ダイオキシン, 塩酸などの有毒物質を発生させる.

塩ビはその代替品に比べて価格が安いように見えるが， それは昔から大量に製造しており，習熟曲線上にいるから であって，代替品でも大量に製造すれば同じような価格に なる.

最も大きな塩ビ用途はパイプであるが，ポリエチレンが 有力な代替品である。すでに塩ビの $15 \%$ に当たるシェア を有している，フローリングはリモネン，ゴム，コルク， Straticaが塩ビ代替と材料である. 初期投資は大きいかも しれないが，代替材料は塩ビに対し，耐久性が高く，メン テナンス費用を含めれば決して高いことはない。

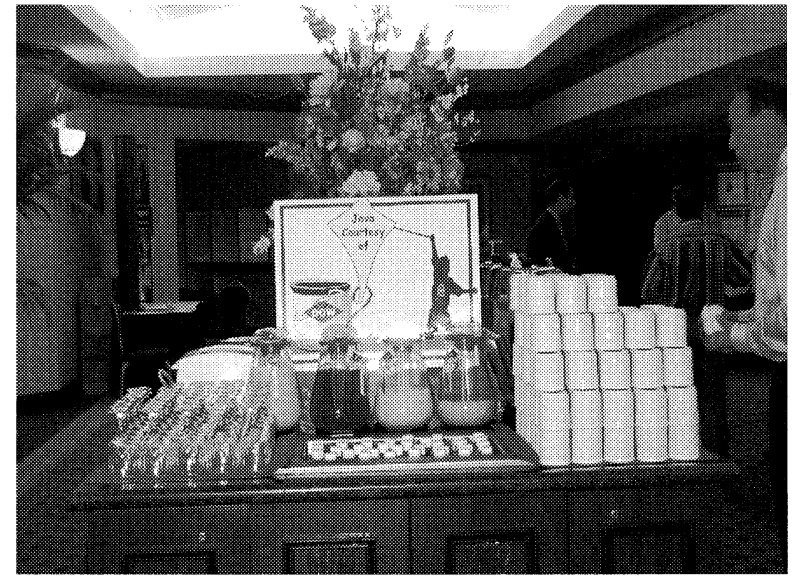

図 3 会場風景

ルーフィングではTPO, EPDMが有力な代替品であり， 置き換わりが進んでいる．塩ビのルーフィングは，10年 間で粉々になったというアメリカ海軍の報告がある.

このように，すでに代替材が塩ビに置き換わっていると ころもあるし，習熟曲線による価格低下があれば代わるで あろうものもある。

\section{NOVA Chemical とBP Petrochemicals の触媒開発に おける協力関係}

Mr, Joseph Welch, Catalyst Licensing Manager NOVA Corporation, Moon Township, PA

ポリエチレンの中堅メーカー（世界で11位)である NOVA Chemical は世界 3 位のポリエチレンメーカーであ る BP Petrochemicals と新触媒の開発を共同でおこなって いる. 2001年から，ガスフェイズZiegler-Natta系触媒の, 2002 年からはメタロセン系触媒の共同開発に着手してい る. Ziegler-Natta系触媒は商品名をNOVACAT触媒とい う. NOVACATにはNOVACAT S, NOVACAT T, NOVACAT Kの三種類がある。NOVACAT S は高強度 ヘキセンLLDPEに好適に使用でき，NOVACAT Tは一 般へキセンLLDPEおよびブテン LLDPEに好適に使用で き，NOVACAT K はブテンLLDPEおよびLDPEに好適 に使用できる. NOVACAT Sの特徵は低べたつき，すぐ れた粒子モルフォロジー，すぐれた収率，すぐれた物性， 低いへキセン抽出率などである．NOVACAT T の特徴は 著しく高い生産性とコモノマーおよび水素の低減可能なこ とである。

具体的なデータをレーダーチャートで示して，スタンダ ードのPEよりすぐれていることを主張していた. 